\title{
STUDY TO PREDICT NEWBORN AT RISK OF DEVELOPING NEONATAL HYPERBILIRUBINAEMIA BY MEASURING CORD BLOOD BILIRUBIN
}

\author{
Uthaya Kumaran ${ }^{1}$, Ajay Kumar Arya2, Ritu Rakholia ${ }^{3}$
}

1 Post Graduate, Department of Paediatrics, Dr. Susheela Tiwari Government Hospital, Haldwani. 2 Professor \& HOD, Department of Paediatrics, Dr. Susheela Tiwari Government Hospital, Haldwani. ${ }^{3}$ Associate Professor, Department of Paediatrics, Dr. Susheela Tiwari Government Hospital, Haldwani.

\begin{tabular}{l}
\hline ABSTRACT \\
\hline BACKGROUND \\
NNH is a common problem in neonates during $1^{\text {st }}$ week of life. Early discharge of healthy-term newborn is a common practice \\
and NNH is a cause for readmission in most babies. Our aim was to predict the risk of NNH using cord bilirubin values. \\
METHODS \\
Around 150 intramurally delivered healthy term neonates were prospectively enrolled. Cord bilirubin and serum bilirubin at or \\
after 72 hours were estimated. \\
RESULTS AND DISCUSSION \\
Using statistical analysis SPSS 19.0 .2 program for windows, significant hyperbilirubinaemia was found in $14 \%$ of the neonates. \\
Using cord bilirubin $>2 \mathrm{mg} / \mathrm{dL}$, significant hyperbilirubinaemia can be predicted with sensitivity of $90.4 \%$, specificity of $75.1 \%$, PPV \\
of $37.2 \%$, NPV of $97.9 \%$ and a p value of $<0.05$.
\end{tabular}

\section{CONCLUSION}

A high NPV in our study suggests that healthy term babies with cord bilirubin $<2 \mathrm{mg} / \mathrm{dL}$ can be discharged early with assurance to parents.

\section{KEYWORDS}

Bilirubin, Hyperbilirubinaemia, Newborn.

HOW TO CITE THIS ARTICLE: Kumaran U, Arya AK, Rakholia R. Study to predict newborn at risk of developing neonatal hyperbilirubinaemia by measuring cord blood bilirubin. J. Evolution Med. Dent. Sci. 2016;5(31):1676-1682,

DOI: $10.14260 /$ jemds/2016/395

\section{INTRODUCTION}

Neonatal hyperbilirubinaemia is a cause of concern for the parents as well as for the paediatricians. ${ }^{1}$ Early discharge of healthy term new-borns after delivery has become a common practice because of medical and social reasons and economic constraints. ${ }^{2,3}$ It is significant that the most common cause for readmission during the early neonatal period is hyperbilirubinaemia. 4,5

Thus the recognition, follow-up and early treatment of jaundice has become more difficult as a result of earlier discharge from the hospital. Severe jaundice and even kernicterus can occur in some full-term healthy new-borns discharged early with no apparent early findings of haemolysis. 6

Jaundice in newborn is quite common affecting nearly $60 \%$ of term and $80 \%$ of preterm neonates during first week of life. ${ }^{7}$ The treatment of severe neonatal jaundice by exchange transfusion is costly, time consuming associated with complications and requires skilled manpower. ${ }^{8}$

Financial or Other, Competing Interest: None.

Submission 16-02-2016, Peer Review 22-03-2016,

Acceptance 28-03-2016, Published 18-04-2016.

Corresponding Author:

Uthaya Kumaran

1/143, Valliammalpuram,

Therkumadathur Post Office,

Alangulam Taluk,

Tirunelveli Dist.,-627423,

Tamilnadu

E-mail: imuthayakumaran@gmail.com

DOI: $10.14260 /$ jemds/2016/395
Early treatment of jaundice with phototherapy is simple, cheap and effective. 9,10

The concept of prediction of jaundice offers an option to pick up babies at risk of neonatal hyperbilirubinaemia. A total serum bilirubin of $>15 \mathrm{mg} / \mathrm{dL}$ is found in $3 \%$ of normal term babies. ${ }^{11}$ The incidence of hyperbilirubinaemia depends upon ethnic variations, regional variations. ${ }^{12,13}$ laboratory variability in measuring serum bilirubin and the incidence of breast feeding. ${ }^{14}$ Several investigators have tried to find a simple marker for predicting hyperbilirubinaemia. Some of them used cord bilirubin estimation. ${ }^{15-23}$ bilirubin estimation during 6 to 24 hours of life. ${ }^{24-27}$ Predischarge hour specific bilirubin estimation. ${ }^{28}$ transcutaneous bilirubin measurement.29-37 and End-Tidal Carbon Monoxide (ETCO) measurement. ${ }^{38,39}$ to predict the subsequent development of neonatal jaundice.

There is an obvious need to develop simple predictive guidelines that will enable the physicians to predict or to identify which of the early discharged new-borns will develop significant hyperbilirubinaemia and thereby minimise the risk of bilirubin dependent brain damage.

Our hospital is a tertiary care centre in the Kumaon region of Uttarakhand where most people come from remote hilly areas where people have to walk for six to eight hours to reach their village and adjoining areas of Uttar Pradesh. Followup of those babies who are discharged from our hospital is extremely difficult and hence need a safe cut-off value of umbilical cord bilirubin value below which we can safely discharge the baby. 
To the best of our knowledge, there are no studies determining the safe cut-off value of umbilical cord bilirubin level in predicting neonatal hyperbilirubinaemia in Kumaon or Garhwal region of Uttarakhand. A Study in our Kumaon region by Veena Prasad and Nutan Singh. 40 in 2013 concluded that umbilical cord blood can be utilized for estimation of serum bilirubin to predict development of neonatal hyperbilirubinaemia and decide the need for appropriate intervention in neonates, but no cut-off value had been determined. This has created interest in the principal investigator to take up this area of research where knowledge gap exists. This study will give a safe cut-off value of umbilical cord blood bilirubin level, below which we can safely discharge healthy term newborn babies.

\section{AIMS AND OBJECTIVES}

To estimate critical cord blood bilirubin level as a predictor of significant hyperbilirubinaemia in healthy new-borns.

\section{METHODS}

The study was conducted in Department of Paediatrics, Government Medical College, Haldwani, attached to Dr. Susheela Tiwari, Government Hospital, Haldwani. Initially around 175 healthy term new-borns born in our hospital during the period from October 2014 to May 2015 were enrolled in the study. Our study was a prospective observational study and approved by the Research Ethics Committee of Dr. Susheela Tiwari, Government Hospital, Haldwani.

\section{Inclusion Criteria}

- Term babies.

- Birth weight $>2.5 \mathrm{~kg}$.

- Apgar $>$ or $=7 / 10$ at $1 \mathrm{~min}$.

\section{Exclusion Criteria}

- Sick babies admitted to newborn care unit (Except for phototherapy) including G6PD deficiency.

- Babies whose mother receiving drugs (AEDs, Antimalarials, sulfonamides).

- Prematurity.

- Major congenital anomalies.

- Birth asphyxia (Apgar $<7$ at $5 \mathrm{~min}$ ).

\section{Method of Collection of Data}

Informed consent was obtained from all the parents of the new-borns to be enrolled for the study. In all the new-borns, relevant information was collected in a predesigned proforma.

- Cord blood was collected in a plain vial at birth for estimation of total bilirubin.

- All enrolled babies were followed up for first 5 postnatal days and clinical assessment for jaundice was done according to Kramer dermal scale.

- Under aseptic precaution $1 \mathrm{~mL}$ of venous blood was drawn in a plain vial from all the babies enrolled in study on or after 72 hours of life for estimation of serum total bilirubin.

Bilirubin estimation was done by Diazo method which is based on the principle that bilirubin reacts with diazotised sulphanilic acid in acidic medium to form pink coloured azobilirubin with absorbance directly proportional to bilirubin concentration. Direct bilirubin, being water soluble directly reacts in acidic medium. However, indirect bilirubin is solubilised using a surfactant and then reacts similar to direct bilirubin. 41

Significant jaundice was defined as total serum bilirubin $>15 \mathrm{mg} / \mathrm{dL}$, which was considered as hyperbilirubinaemia requiring phototherapy according to AAP guidelines.

\section{Analysis of Data}

The data were compiled and entered in MS Excel sheet and the analysis was carried out using the Statistical Package for the Social Sciences (SPSS 19.0.2) program for windows. The critical bilirubin level, measured from the umbilical cord blood having the highest sensitivity, was determined with the Receiver Operating Characteristic (ROC) curve analysis. Statistical test using chi-square test of significance was applied and the predictive values (Sensitivity, specificity, Positive Predictive Value (PPV), and Negative Predictive Value (NPV) were calculated using the conventional formulae. $\mathrm{P}$ values with significance of 0.05 were considered statistically significant. All infants were classified into 4 groups depending on the UCSB levels $<1 \mathrm{mg} / \mathrm{dL}$ (group-I), 1.1 to $2 \mathrm{mg} / \mathrm{dL}$ (groupII), 2.1 to $3 \mathrm{mg} / \mathrm{dL}$ (group-III), and $>3 \mathrm{mg} / \mathrm{dL}$ (group-IV).

\section{RESULTS}

Out of total 175 new-borns 25 neonates were excluded from the study and of the remaining 150 new-borns 21 developed significant jaundice. The incidence of significant jaundice requiring phototherapy in our study population is $14 \%$ of total new-borns.

\begin{tabular}{|c|c|c|c|c|}
\hline \multirow{2}{*}{$\begin{array}{c}\text { Maternal } \\
\text { Details }\end{array}$} & \multicolumn{2}{|c|}{ Total } & Phototherapy \\
\cline { 2 - 5 } & Number & $\mathbf{\%}$ & Number & \% \\
\hline \multicolumn{4}{|c|}{ Age of Mother in Years (P=0.258 Not Significant) } \\
\hline$<25$ & 92 & 61.3 & 15 & 16.3 \\
\hline $26-30$ & 51 & 34 & 4 & 7.8 \\
\hline $31-35$ & 6 & 4 & 2 & 33.3 \\
\hline$>35$ & 1 & 0.7 & 0 & 0 \\
\hline \multicolumn{5}{|c|}{ Order of Birth (P=0.807 Not Significant) } \\
\hline 1 & 85 & 56.7 & 13 & 15.3 \\
\hline 2 & 51 & 34 & 6 & 11.7 \\
\hline 3 & 11 & 7.3 & 2 & 18.2 \\
\hline 4 & 3 & 2 & 0 & 0 \\
\hline \multicolumn{5}{|c|}{ Mode of Delivery (P=1 Not Significant) } \\
\hline NVD & 60 & 40 & 8 & 13.3 \\
\hline LSCS & 90 & 60 & 13 & 14.4 \\
\hline \multicolumn{7}{|c|}{ Table 1: Maternal Factors and Requirement of } \\
Phototherapy \\
\hline
\end{tabular}

In this study, $60(40 \%)$ were delivered by Normal Vaginal Delivery (NVD) and 90 (60\%) by Lower Segment Caesarean Section (LSCS). This may be because most antenatal cases are referred from distant hilly areas to our hospital, which is a tertiary care centre in the Kumaon region of Uttarakhand. The number of infants born by NVD who developed hyperbilirubinaemia were $8(13.3 \%)$ as compared to those who required phototherapy born by LSCS (14.4\%) and this was not statistically significant (Table 1). 


\begin{tabular}{|c|c|c|c|c|}
\hline \multirow{2}{*}{\begin{tabular}{c} 
Details $\begin{array}{c}\text { of } \\
\text { Neonates }\end{array}$ \\
\cline { 2 - 5 }
\end{tabular}} & Number & $\%$ & Number & $\%$ \\
\hline \multicolumn{5}{|c|}{ Sex (P=0.69 Not Significant) } \\
\hline Male & 87 & 58 & 16 & 18.4 \\
\hline Female & 63 & 42 & 5 & 7.9 \\
\hline \multicolumn{5}{|c|}{ Gestation Weeks (P=0.129 Not Significant) } \\
\hline $37-39$ & 63 & 42 & 12 & 19 \\
\hline $40-42$ & 87 & 58 & 9 & 10.3 \\
\hline Birth Weight in Kilograms (P=0.855 Not Significant) \\
\hline $2.50-2.99$ & 82 & 54.7 & 11 & 13.4 \\
\hline $3.00-3.49$ & 50 & 33.3 & 8 & 16 \\
\hline $3.50-4.00$ & 18 & 12 & 2 & 11.1 \\
\hline \multicolumn{7}{|c|}{ Table 2: Neonatal Factors and Requirement of } \\
Phototherapy \\
\hline
\end{tabular}

No significant association between neonatal factors and significant jaundice requiring phototherapy was found in this study (Table 2).

\begin{tabular}{|c|c|c|c|c|}
\hline \multirow{2}{*}{$\begin{array}{c}\text { Risk } \\
\text { Factors }\end{array}$} & \multicolumn{2}{|c|}{ Total } & \multicolumn{2}{|c|}{ Phototherapy } \\
\hline & Number & $\%$ & Number & $\%$ \\
\hline \multicolumn{5}{|c|}{ Oxytocin Use ( $\mathrm{P}=0.311$ Not Significant $)$} \\
\hline Yes & 8 & 5.3 & 2 & 25 \\
\hline No & 142 & 94.7 & 19 & 13.3 \\
\hline \multicolumn{5}{|c|}{ Feeds (P=1.000 Not Significant) } \\
\hline Mother & 85 & 56.7 & 12 & 14.1 \\
\hline $\begin{array}{l}\text { Both Mother \& top } \\
\text { feeds }\end{array}$ & 65 & 43.3 & 9 & 13.8 \\
\hline \multicolumn{5}{|c|}{ Jaundice in Previous Siblings ( $\mathrm{P}=1.000$ Not Significant $)$} \\
\hline Yes & 8 & 5.3 & 1 & 12.5 \\
\hline No & 142 & 94.7 & 20 & 14.1 \\
\hline \multicolumn{5}{|c|}{ PIH (P=0.601 Not Significant) } \\
\hline Yes & 8 & 5.3 & 0 & 0 \\
\hline No & 142 & 94.7 & 21 & 14.8 \\
\hline \multicolumn{5}{|c|}{ Meconium ( $\mathrm{P}=0.632$ Not Significant) } \\
\hline Yes & 10 & 6.7 & 2 & 20 \\
\hline No & 140 & 93.3 & 19 & 13.6 \\
\hline \multicolumn{5}{|c|}{ PROM (P = 0.375 Not Significant $)$} \\
\hline Yes & 30 & 20 & 6 & 20 \\
\hline No & 120 & 80 & 15 & 12.5 \\
\hline \multicolumn{5}{|c|}{ Signs of External Bleeding ( $\mathrm{P}=0.008$ Highly Significant $)$} \\
\hline Yes & 7 & 4.7 & 4 & 57.1 \\
\hline No & 143 & 95.3 & 17 & 11.9 \\
\hline \multicolumn{5}{|c|}{ APH (P = 1.000 Not Significant $)$} \\
\hline Yes & 2 & 1.3 & 0 & 0 \\
\hline No & 148 & 98.7 & 21 & 14.2 \\
\hline $\begin{array}{r}\text { Table } 3 \\
\text { Requ }\end{array}$ & ernal $\mathrm{F}$ & Fac & $\begin{array}{l}\text { s and } \\
\text { py }\end{array}$ & \\
\hline
\end{tabular}

Mothers with risk factors including oxytocin use, jaundice in previous siblings, pregnancy-induced hypertension, meconium stained liquor, premature rupture of membranes, antepartum haemorrhage had no significant association with requirement of phototherapy. Neonates with signs of external bleeding like cephalhaematoma were 7 $(4.7 \%)$ of which $4(57.1 \%)$ required phototherapy, which was statistically highly significant $(\mathrm{P}<0.01)$ (Table 3$)$.
In this study, there was an association found between the blood group of the mother and development of neonatal hyperbilirubinaemia which was statistically significant.

Also neonates born with ABO incompatibility were 34 (22.7\%), Rh incompatibility were 3 (2\%) of which 14 (41.1\%) and $1(33.3 \%)$ required phototherapy respectively, which was statistically significant $(\mathrm{P}<0.05)$ (Table 4$)$.

\begin{tabular}{|c|c|c|c|c|}
\hline \multirow{2}{*}{$\begin{array}{c}\text { Blood } \\
\text { Group }\end{array}$} & \multicolumn{2}{|c|}{ Total } & \multicolumn{2}{c|}{ Phototherapy } \\
\cline { 2 - 5 } Number & \% & \multicolumn{2}{c|}{ Number } & \% \\
\hline Mother's Blood Group (P=0.09 Significant) \\
\hline A + & 36 & 24 & 1 & 2.7 \\
\hline B + & 42 & 28 & 4 & 9.5 \\
\hline O + & 47 & 31.3 & 13 & 27.7 \\
\hline AB + & 20 & 13.3 & 2 & 10 \\
\hline A - & 1 & 0.7 & 0 & 0 \\
\hline B - & 2 & 1.3 & 0 & 0 \\
\hline O - & 1 & 0.7 & 0 & 0 \\
\hline AB - & 1 & 0.7 & 1 & 100 \\
\hline Neonates Blood Group (P=0.188 Not Significant) \\
\hline A + & 57 & 38 & 12 & 21.1 \\
\hline B + & 40 & 26.7 & 7 & 17.5 \\
\hline O + & 45 & 30 & 2 & 4.4 \\
\hline AB + & 5 & 3.3 & 0 & 0 \\
\hline A - & 2 & 1.3 & 0 & 0 \\
\hline B - & 1 & 0.7 & 0 & 0 \\
\hline O - & 0 & 0 & 0 & 0 \\
\hline AB - & 0 & 0 & 0 & 0 \\
\hline \multicolumn{6}{|c|}{ Incompatibility (P=0.000 Highly Significant) } \\
\hline ABO & 34 & 22.7 & 14 & 41.1 \\
\hline Rh & 3 & 2 & 1 & 33.3 \\
\hline $\begin{array}{c}\text { No } \\
\text { incompatibil } \\
\text { ity }\end{array}$ & 113 & 75.3 & 6 & 5.3 \\
\hline Table 4 Blood Group and Requirement of Phototherapy \\
\hline
\end{tabular}

Table 4: Blood Group and Requirement of Phototherapy

\begin{tabular}{|c|c|c|c|c|}
\hline \multirow{2}{*}{$\begin{array}{c}\text { Cord Bilirubin in } \\
\text { mg/dL }\end{array}$} & \multicolumn{2}{|c|}{ Total } & \multicolumn{2}{c|}{ Phototherapy } \\
\cline { 2 - 5 } & Number & $\mathbf{\%}$ & Number & $\mathbf{\%}$ \\
\hline \multicolumn{4}{|c|}{$\begin{array}{c}\text { Association between cord bilirubin and requirement } \\
\text { of phototherapy (P<0.05 Significant) }\end{array}$} \\
\hline $\begin{array}{c}\text { 1st group } \\
(<1)\end{array}$ & 2 & 1.3 & 0 & 0 \\
\hline 2nd group (1.1-2) $^{\text {grd group }}$\begin{tabular}{c} 
(2.1 -3) \\
\hline $\begin{array}{c}\text { 4th group } \\
(>3)\end{array}$
\end{tabular} & 39 & 26 & 8 & 20.5 \\
\hline
\end{tabular}

Association between cord bilirubin and requirement of Phototherapy with taking $>2 \mathrm{mg} / \mathrm{dL}$ level as cut-off $(\mathrm{P}<0.05$ Significant $)$

\begin{tabular}{|l|c|c|c|c|}
$>2$ & 51 & 34 & 19 & 37.3 \\
\hline$<2$ & 99 & 66 & 2 & 2 \\
\hline
\end{tabular}

Table 5: Predictive Ability of Hyperbilirubinaemia Requiring Phototherapy using Cord Bilirubin Level

Out of total 150 neonates $2(1.3 \%)$ were in Group I (cord bilirubin <1 mg/dL), 97 (64.7\%) were in Group II (Cord bilirubin 1.1-2 mg/dL), 39 (26\%) were in Group III (Cord bilirubin $2.1-3 \mathrm{mg} / \mathrm{dL}$ ) and $12(8 \%)$ neonates were in Group IV (Cord bilirubin $>3 \mathrm{mg} / \mathrm{dL}$ ) (Table 5). 
Among 21 new-borns who required phototherapy, majority 11 (52.4\%) were in Group IV and none in Group I. There was statistically highly significant $(\mathrm{P}<.001)$ association between requirement of phototherapy and increasing cord bilirubin levels. This study shows that number of infants requiring phototherapy proportionately increased as the cord bilirubin increased, i.e. from $2 \%$ in Group II to $91.7 \%$ in Group IV (Table 5).

With ROC analysis, a mean umbilical cord bilirubin level of $>2 \mathrm{mg} / \mathrm{dL}$ was determined to have the highest sensitivity and specificity to predict the new-borns who would develop significant hyperbilirubinaemia. In this study, using cord bilirubin level of $>2 \mathrm{mg} / \mathrm{dL}$, hyperbilirubinaemia could be predicted with sensitivity of $90.4 \%$, specificity of $75.1 \%$, Positive Predictive Value (PPV) of $37.2 \%$ and Negative Predictive Value (NPV) of $97.9 \%$.

At this critical mean serum bilirubin level, the NPV was very high and the PPV was fairly low. Of the 51 new-borns who had a cord bilirubin level of $>2 \mathrm{mg} / \mathrm{dL}, 19$ (37.3\%) developed significant hyperbilirubinaemia in first 5 days of life, whereas only $2(2 \%)$ of the 99 new-borns who had cord bilirubin level of $<2 \mathrm{mg} / \mathrm{dL}$ developed significant hyperbilirubinaemia later on. The area under ROC curve is 0.9 (95\% CI 0.81 to 0.98 , pvalue $<0.05$ ) when cord bilirubin level of $2 \mathrm{mg} / \mathrm{dL}$ was used as a screening test (Graph 1).

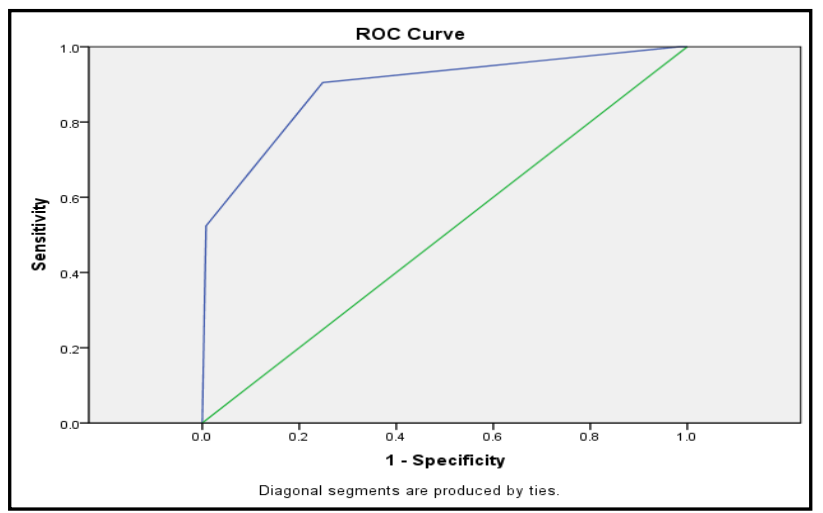

Fig. 1: ROC Curve for Cut-Off Value of the Cord Blood Bilirubin for Prediction of Significant Hyperbilirubinaemia

\begin{tabular}{|c|c|c|c|c|}
\hline $\begin{array}{c}\text { Cord } \\
\text { Bilirubin } \\
\text { in } \\
\text { mg/dL }\end{array}$ & $\begin{array}{c}\text { Sensitivity } \\
\text { (\%) }\end{array}$ & $\begin{array}{c}\text { Specificity } \\
\text { (\%) }\end{array}$ & $\begin{array}{c}\text { Positive } \\
\text { Predictive } \\
\text { Value (\%) }\end{array}$ & $\begin{array}{c}\text { Negative } \\
\text { Predictive } \\
\text { Value (\%) }\end{array}$ \\
\hline 1.5 & 95.2 & 27.13 & 17.5 & 97.2 \\
\hline 2 & 90.4 & 75.1 & 37.2 & 97.9 \\
\hline 3 & 52.3 & 99.2 & 91.6 & 92.7 \\
\hline \multicolumn{4}{|c|}{ Table 6: Validity and Predictive Values of Cord } \\
Bilirubin in Assessing Hyperbilirubinaemia \\
\hline
\end{tabular}

\section{DISCUSSION}

Serum bilirubin levels are usually $1-3 \mathrm{mg} / \mathrm{dL}$ at the time of birth and rise at the rate of less than $5 \mathrm{mg} / \mathrm{dL} /$ day, peaking at 2-3 days in term neonates. Our study hypothesis was that a high serum bilirubin level at birth would also predict a high peak later in life. Our aim was to quantify the relationship between cord blood bilirubin with peak serum bilirubin levels of the first five days. We chose cord blood estimation for initial serum bilirubin estimation, because it is a non-invasive way and the result is available within few hours after birth.
The growing practice of early discharge of new-borns has resulted in a re-emergence of bilirubin-related neurological sequelae. Therefore, it is important to establish safe markers to detect babies at risk for significant hyperbilirubinaemia. Development of safe marker will help in preventing fatal outcome due to jaundice. To address this issue, AAP recommends that follow-up should be provided to all neonates discharged less than 48 hours after birth by a health care professional in an office, clinic or at home within 2 to 3 days of discharge. Compliance with this advice may not be easy, however, particularly in rural or lower socio-economic areas and given the rarity of kernicterus it will be very difficult if not possible to document the benefits of this policy.

The experience of mothers in observing infants for the development of jaundice is not satisfactory. Despite such instructions, it is difficult for many parents to recognize significant jaundice.

Currently, we do not have a reliable method of anticipating such levels of hyperbilirubinaemia. It is possible that closer and more frequent follow-up after birth and discharge from the hospital might prevent development of kernicterus, but rare sporadic cases of kernicterus may not be preventable unless we adopt an approach to surveillance of the newborn that is substantially more rigorous than has been practised. The feasibility, costs, risks and benefits of such an approach need to be determined.

Umbilical cord blood collection is not associated with any pain. Furthermore, most important is that the data are available immediately after birth. The babies at risk for developing hyperbilirubinaemia can be detected at birth in a non-invasive way if the neonate leaves the hospital within the first few postnatal days. The use of cord blood bilirubin values may help to predict infants with low risk for hyperbilirubinaemia and minimise an unnecessary prolongation of hospitalization.

Keeping these factors in consideration, our study was conducted on term healthy neonates born in Dr. Susheela Tiwari Government Hospital, Haldwani. The outcome was hyperbilirubinaemia. We have considered peak serum bilirubin level $>15 \mathrm{mg} / \mathrm{dL}$ at or more than 72 hours of age as significant hyperbilirubinaemia since specific treatment is considered at or above this level.

The prevalence of hyperbilirubinaemia in this study was $14 \%$, which is comparable to $10 \%$ to $15 \%$ in various other studies. ${ }^{15,16,20}$ In a study by Bernaldo AJ, Segre CA. ${ }^{21}$ prevalence was $19.86 \%$ as no cut-off was mentioned for bilirubin level on third day of life above which phototherapy was required, whereas in a study by Taksande et al. ${ }^{42}$ prevalence was $9.5 \%$ only because the cut-off for significant hyperbilirubinaemia on $3^{\text {rd }}$ day of life was taken as $17 \mathrm{mg} \%$.

\begin{tabular}{|c|c|c|c|}
\hline Study & Year & $\begin{array}{l}\text { Number } \\
\text { of Cases }\end{array}$ & $\begin{array}{c}\text { Hyperbilirubina } \\
\text { emia (\%) }\end{array}$ \\
\hline Palmer.43 & 1983 & 41057 & 10.7 \\
\hline Alpay et al. ${ }^{25}$ & 2000 & 498 & 12.05 \\
\hline Bernaldo AJ. ${ }^{21}$ & 2004 & 380 & 19.86 \\
\hline Knupfer et al.22 & 2005 & 1100 & 10.6 \\
\hline $\begin{array}{l}\text { Taksande } \\
\text { et al.42 }\end{array}$ & 2005 & 200 & 9.5 \\
\hline Zakia et al.44 & 2009 & 84 & 15.5 \\
\hline $\begin{array}{l}\text { Randev S } \\
\text { et al. }{ }^{27}\end{array}$ & 2010 & 200 & 12 \\
\hline \multicolumn{4}{|c|}{$\begin{array}{c}\text { Table 7: Comparison of Prevalence of } \\
\text { Hyperbilirubinaemia }\end{array}$} \\
\hline
\end{tabular}


Sex ratio in this study was $1.38: 1$. The prevalence of hyperbilirubinaemia was more in males as compared to females, but this was not found to be significant which is comparable with studies by Bernaldo, Seidman et al. and Newman et al.21,45,46 (Table 2).

Majority of the deliveries in this study were caesarean sections (60\%), while $40 \%$ were normal vaginal deliveries and was statistically not significant. This is in agreement to a study done by Suchonska et al. in which no significant relation was found between route of delivery and neonatal hyperbilirubinaemia. However, in a study done by Phelan et al. significant correlation between babies born by normal deliveries and significant jaundice was there. 20,47 (Table 1).

In this study, most infants were first in birth order (85\%), but with no significant association between hyperbilirubinaemia and birth order. This is not in similar with the findings of a study by Phelan et al. where primiparous mothers are more likely to have jaundiced infants. ${ }^{47}$ (Table 1).

In this study, no significant association was found between maternal age and development of hyperbilirubinaemia in new-borns. This is in agreement with a study done by Srivastav et al. ${ }^{48}$ However, studies done by Seidman et al., Newman et al. and Rakesh et al. have found that there is a significant association between jaundice and increasing maternal age. $45,46,49$ (Table 1 ).

The mean cord bilirubin level was $1.93 \pm 0.65 \mathrm{mg} / \mathrm{dL}$ in the present study and the number of new-borns with significant hyperbilirubinaemia increased with increasing UCSB levels in this study.

\begin{tabular}{|c|c|c|c|c|c|c|}
\hline Study & $\begin{array}{l}\text { Knud- } \\
\text { sen.16 } \\
(\%)\end{array}$ & $\begin{array}{c}\text { Knupfer } \\
\text { et al. }{ }^{22} \text { (\%) }\end{array}$ & $\begin{array}{c}\text { Taksande } \\
\text { et al. }{ }^{43} \\
(\%)\end{array}$ & $\begin{array}{c}\text { Zakia } \\
\text { et al.44 } \\
(\%)\end{array}$ & \begin{tabular}{|c|} 
Singha \\
IV \\
et al..$^{50}$ \\
$(\%)$ \\
\end{tabular} & $\begin{array}{c}\text { Present } \\
\text { Study } \\
(\%)\end{array}$ \\
\hline $\begin{array}{c}\text { Cord } \\
\text { bilirubin } \\
\text { in } \mathrm{mg} / \mathrm{dL}\end{array}$ & 2.33 & 1.74 & 2 & 2.5 & 1.9 & 2 \\
\hline $\begin{array}{l}\text { Sensiti- } \\
\text { vity }\end{array}$ & 13 & 97 & 89.5 & 77 & 90 & 90.4 \\
\hline $\begin{array}{l}\text { Specifi- } \\
\text { city }\end{array}$ & 99 & 41.4 & 85.1 & 98 & 82.6 & 75.1 \\
\hline PPV & 85 & 4.8 & 38.6 & 91 & 45.7 & 37.2 \\
\hline NPV & 72 & 99.8 & 98.7 & 96 & 98.1 & 97.9 \\
\hline \multicolumn{7}{|c|}{ Table 8: Statistics and Predictive Ability of UCSB } \\
\hline
\end{tabular}

In the present study, UCSB value of $2 \mathrm{mg} / \mathrm{dL}$ was considered as cut-off to predict subsequent hyperbilirubinaemia requiring phototherapy in view of an increase in the percentage of neonates developing hyperbilirubinaemia above this value $(2.1 \%-20.5 \%)$ between the two groups. With lower cut-off value (As with the study by Knupfer et al.22) sensitivity and NPV increases, but specificity and PPV decreases. If a higher cut-off value is considered (As with the study by Knudsen. ${ }^{16}$ Zakia et $a l .{ }^{44}$ ) specificity and PPV increases, but sensitivity and NPV decreases. Hence, considering a cut-off of $2 \mathrm{mg} / \mathrm{dL}$ in this study has resulted in fairly comparable sensitivity and NPV to that of the study by Knupfer et al. and higher specificity and PPV (Table 8).

\begin{tabular}{|c|c|c|c|}
\hline Study & Year & $\begin{array}{c}\text { Cord } \\
\text { Bilirubin in } \\
\text { mg/dL } \\
\end{array}$ & $\begin{array}{c}\text { Hyperbilirubinaemia } \\
\text { (\%) }\end{array}$ \\
\hline \multirow{2}{*}{ Knudsen. ${ }^{16}$} & \multirow{2}{*}{1989} & $<1.17$ & 2.9 \\
\hline & & $>2.34$ & 85 \\
\hline \multirow{2}{*}{$\begin{array}{l}\text { Rataj } \\
\text { et al.19 }\end{array}$} & \multirow{2}{*}{1994} & $<1$ & 2.4 \\
\hline & & $>2.5$ & 89 \\
\hline \multirow{2}{*}{$\begin{array}{c}\text { Bernaldo } \\
\text { AJ. }{ }^{21}\end{array}$} & \multirow{2}{*}{2004} & $<2$ & 0 \\
\hline & & $>2$ & 53 \\
\hline \multirow{4}{*}{$\begin{array}{l}\text { Knupfer } \\
\text { et al. }{ }^{22}\end{array}$} & \multirow{4}{*}{2005} & $<1.17$ & 0 \\
\hline & & $1.17-1.75$ & 0.3 \\
\hline & & $1.75-2.34$ & 3.4 \\
\hline & & $>2.34$ & 8.6 \\
\hline \multirow{2}{*}{$\begin{array}{c}\text { Taksande } \\
\text { et al. }{ }^{43}\end{array}$} & \multirow{2}{*}{2005} & $<2$ & 2 \\
\hline & & $>2$ & 17 \\
\hline \multirow{2}{*}{$\begin{array}{l}\text { Zakia } \\
\text { et al.44 }\end{array}$} & \multirow{2}{*}{2009} & $<2.5$ & 4.1 \\
\hline & & $>2.5$ & 90.9 \\
\hline \multirow{4}{*}{$\begin{array}{l}\text { Present } \\
\text { Study }\end{array}$} & \multirow{4}{*}{2015} & $<1$ & 0 \\
\hline & & $1.1-2$ & 2.1 \\
\hline & & $2.1-3$ & 20.5 \\
\hline & & $>3$ & 91.7 \\
\hline
\end{tabular}

Present study shows that there is significant association between rising cord bilirubin level and development of jaundice in subsequent postnatal days, which is in comparison with other studies (Table 9). As the umbilical cord bilirubin level increases, the risk of developing hyperbilirubinaemia also increases exponentially. Hence, cord bilirubin can be considered as an useful indicator of predicting subsequent neonatal hyperbilirubinaemia and aids in identifying the low risk group children with UCSB level of $<2 \mathrm{mg} / \mathrm{dL}$. NPV in this low risk group can prove useful in using this parameter for making decisions regarding early discharge or request for review of the new-borns for evaluating neonatal hyperbilirubinaemia.

To optimize utilization of the limited neonatal care facility available in our country, it is essential to have practical guidelines to predict which new-born would develop significant jaundice and to avoid preventable kernicterus. From the present study, it can be concluded that estimation of cord bilirubin considering the critical bilirubin level of $>2$ $\mathrm{mg} / \mathrm{dL}$ at birth will help predict nearly all healthy term newborns who would have significant jaundice and will require a phototherapy treatment later during first few days of life. It can also be concluded that new-borns with cord bilirubin level of $<1 \mathrm{mg} / \mathrm{dL}$ are unlikely to have neonatal hyperbilirubinaemia.

\section{Limitations}

1. The main limitation of the study was small sample size as the duration of study was only eight months.

2. In this study, preterm babies and low birth weight babies between 1.5 and $2.5 \mathrm{~kg}$ were not included. There is a practice that these babies are discharged on day 3 and there is a high chance that these babies may develop jaundice and kernicterus if not followed up. 
3. Mothers with both $\mathrm{ABO}$ and $\mathrm{Rh}$ incompatibility were included in the study, which may produce a bias in the results as the babies born to these mothers are at increased risk of developing jaundice.

\section{CONCLUSION}

In our setting, infants having umbilical cord blood bilirubin $>2$ $\mathrm{mg} / \mathrm{dL}$ should be followed up strictly either in hospital or at an outpatient department on day 5 if practicable. Infants having TSB $<2 \mathrm{mg} / \mathrm{dL}$ in cord blood can be discharged early.

Thus, we recommend that cord blood sample should be collected in all term healthy babies born in district and peripheral hospital in the Kumaon region of Uttarakhand for measurement of cord blood bilirubin and those babies with cord bilirubin level less than $2 \mathrm{mg} / \mathrm{dL}$ can be safely discharged early on day $2 / 3$ without any risk of further development of jaundice or kernicterus.

\section{REFERENCES}

1. Mishra S, Agarwal R, Deorari AK, et al. Jaundice in the newborns. Ind J Paediatr 2008;75(2):157-63.

2. Catz C, Hanson JW, Simpson L, et al. Summary of workshop: early discharge and neonatal hyperbilirubinaemia. Paediatrics 1995;96(4):743-5.

3. Escobar GJ, Braveman PA, Ackerson L, et al. A randomized comparison of home visits and hospitalbased group follow-up visits after early postpartum discharge. Paediatrics 2001;108(3):719-27.

4. Radmacher P, Massey C, Adamkin D. Hidden morbidity with successful early discharge. J Perinatol 2002;22(1):15-20.

5. Kiely M, Drum MA, Kessel W. Early discharge risks, benefits and who decides. Clin Perinatol 1998;25(3):539-53, vii-viii.

6. Seidman DS, Stevenson DK, Ergaz Z, et al. Hospital readmission due to neonatal hyperbilirubinaemia. Paediatrics 1995; 96(4 pt 1):727-9.

7. Kliegman M, Stanton BF, Geme JW, et al. Nelson textbook of paediatrics. Philadelphia: Saunders Elsevier, 2011; $19^{\text {th }}$ ed.

8. Bhutani VK, Schwoebel A, Johnson LH. Serious Adverse events related to neonatal exchange transfusion. J Neonatol 2001;1:32-8.

9. Deorari AK, Agarwal R. Phototherapy units. J Neonatol 2001;1:61-8.

10. Dutta S. Phototherapy for neonatal jaundice-recent advances and controversies. J Neonatol 2001;1(1):3944.

11. Cloherty JP, Eichenwald EC, Hansen AR, et al. Manual of neonatal care. Philadelphia: Lippincott Williams \& Wilkins, 2012; $7^{\text {th }}$ ed.

12. Bahi L, Sharma R, Sharma J. Etiology of neonatal jaundice in Shimla. Indian Paediatr 1994;31(10):1275-8.

13. Murki S, Kumar P, Majumdar S, et al. Risk factors of kernicterus in term babies with non haemolytic jaundice. Indian Paediatr 2001;38(7):757-62.

14. Moyer VA, Ahn C, Sneed S. Accuracy of clinical judgement in neonatal jaundice. Arch Paediatr Adolesc Med 2000;154(4):391-4.

15. Rosenfeld J. Umbilical cord bilirubin levels as a predictor of subsequent hyperbilirubinaemia. J Fam Pract 1986;23(6):556-8.
16. Knudsen A. Prediction of the development of neonatal jaundice by increased umbilical cord blood bilirubin. Acta paediatr scand 1989;78(2):217-21.

17. Ho NK. Neonatal jaundice a second 4 year experience in toa payoh hospital (1986-1989). J Singapore Paediatr Soc 1991;33(3-4):149-55.

18. Phuapradit W, Chaturachinda K, Auntlamai S. Risk factors for neonatal hyperbilirubinaemia. J Med Assoc Thai 1993;76(8):424-8.

19. Rataj J, Kornacka M, Korman E. Usefulness of measuring bilirubin levels in cord blood for predicting hyperbilirubinaemia in newborns. Ginekol Pol 1994;65(6):276-80.

20. Suchonska B, Wielgos $M$, Bobrowska $K$, et al. Concentration of bilirubin in the umbilical blood as indicator of hyperbilirubinaemia in newborns. Ginekol Pol 2004;75(10):749-53.

21. Bernaldo AJ, Segre CA. Bilirubin dosage in cord blood: could it predict neonatal hyperbilirubinaemia? Sao Paulo Med J 2004;122(3):99-103.

22. Knupfer M, Pulzer F, Gebauer C, et al. Predictive value of umbilical cord blood bilirubin for postnatal hyperbilirubinaemia. Acta Paediatr 2005;94(5):581-7.

23. Sun G, Wang YL, Liang JF, et al. Predictive value of umbilical cord blood bilirubin level for subsequent neonatal jaundice. Zhonghua $\mathrm{Er} \mathrm{Ke} \mathrm{Za}$ Zhi 2007;45(11):848-52.

24. Awasthi S, Rehman H. Early prediction of neonatal hyperbilirubinaemia. Indian J Paediatr 1998;65(1):1319.

25. Alpay F, Sarici SU, Tosuncuk HD, et al. The value of first day bilirubin measurement in predicting development of significant hyperbilirubinaemia in healthy term newborn. Paediatrics 2000;106(2):e16.

26. Agarwal R, Deorari AK. Unconjugated hyperbilirubinaemia in newborn: current perspective. Indian Paediatr 2002;39:30-42.

27. Randev S, Grower N. Predicting neonatal hyperbilirubinaemia using first day serum bilirubin levels. Indian J Paediatr 2010;77(2):147-50. doi: 10.1007/s12098-009-0335-3.

28. Bhutani VK, Johnson L, Sivieri EM. Predictive ability of a predischarge hour-specific serum bilirubin for subsequent significant hyperbilirubinaemia in healthy term and near-term newborns. Paediatrics 1999;103(1):6-14.

29. Yamauchi Y, Yamonouchi I. Clinical application of transcutaneous bilirubin measurement early prediction of hyperbilirubinaemia. Acta Paediatr Scand 1990;79(4):385-90.

30. Bhutta ZA, Yusuf K. Transcutaneous bilirubinometry in Pakistani newborns: a preliminary report. J Pak Med Assoc 1991;41(7):155-6.

31. Gupta PC, Kumari S, Mullick DN, et al. Icterometer: a useful screening tool for neonatal jaundice. Indian Paediatr 1991;28(5):473-6.

32. Laeeq A, Yasum M, Choudary AR. Transcutaneous bilirubinometry; clinical applications. J Pak Med Assoc 1993;43(2):28-30.

33. Kumar A, Faridi MM, Singh N, et al. Transcutaneous bilirubinometry in the management of bilirubinaemia in term neonates. Indian J Med Res 1994;99:227-30. 
34. Suckling RJ, Laing IA, Kirk JM. Transcutaneous bilirubinometry as a screening tool for neonatal jaundice. Scott Med J 1995;40(1):14-5.

35. Leite MD, Granato Vde A, Facchini FP, et al. Comparison of transcutaneous and plasma bilirubin measurement. J Paediatr (Rio J) 2007;83(3):283-6.

36. Varvarigou A, Fouzas S, Skylogianni E, et al. Transcutaneous bilirubin nomogram for prediction of significant neonatal hyperbilirubinaemia. Paediatrics 2009;124(4):1052-9. doi: 10.1542/peds.2008-2322.

37. Maisels MJ, Ostrea EJ Jr, Touch S, et al. Evaluation of a new transcutaneous bilirubinometer. Paediatrics 2004;113(6):1628-35.

38. Stevenson DK, Vreman HJ, Wong RJ, et al. Carbon monoxide and bilirubin production in neonates. Semin Perinatol 2001;25(2):85-93.

39. Smith DW, Hopper AO, Shahin SM, et al. Neonatal bilirubin production estimated from "end-tidal" carbon monoxide concentration. J Paediatr Gastroenterol Nutr 1984;3(1):77-80.

40. Veena Prasad, Nutan singh. A study on blood bilirubin levels in tertiary care centre of kumaon region (Uttarakhand) India. Journal of Biomedical and Pharmaceutical Research 2013;2(5):77-83.

41. Talwar GP, Srivastava LM. Textbook of biochemistry and human biology. New Delhi: Asoke K Ghosh, Prentice hall of India private limited, 2006; $3^{\text {rd }}$ ed.

42. Taksande A, Vilhekar K, Jain M, et al. Prediction of the development of neonatal hyperbilirubinaemia by increased umbilical cord blood bilirubin. Curr Paediatr Res 2005;9(1 \& 2):5-9.
43. Palmer DC, Drew JH. Jaundice: a 10 year review of 41,000 live born infants. Aust Paediatr J 1983;19(2):86-9.

44. Nahar Z, Mannan SA, Dey SK, et al. The value of umbilical cord blood bilirubin measurement in predicting the development of significant hyperbilirubinaemia in healthy newborn. Bangladesh J Child Health 2009;33(2):50-4.

45. Okuyana H, Yonetani M, Uetani Y, et al. End-tidal carbon monoxide is predictive for neonatal non-hemolytic hyperbilirubinaemia. Paediatr Int 2001;43(4):329-33.

46. Newman M, Liljestrand P, Escobar GJ. Jaundice noted in the first 24 hours after birth in a managed care organization. Arch Paediatr Adolesc Med 2002;156(12):1244-50.

47. Phelan GJ, Taylor JA, Liu LL, et al. Early newborn hospital discharge and readmission for mild and severe jaundice. Arch Paediatr Adolesc Med 1999;153(12):1283-8.

48. Srivastava N, Pande US, Malik GK, et al. A study of serum bilirubin in neonates in relation to the maternal age. Indian J Med Sci 1999;53(4):158-61.

49. Lodha $R$, Deorari AK, Jatana $V$, et al. Non-invasive estimation of total serum bilirubin by multi wavelength spectral reflectance in neonates. Indian Paediatr 2000;37(7):771-5.

50. Singhal V, Nutan Kamath, Baliga BS, et al. Cord blood bilirubin level as an early predictor of neonatal hyperbilirubinaemia-a hospital based prospective study. Perinatology 2012;13(1):1-8. 